UNIVERSITY OF COPENHAGEN

Personality, Education and Earnings

Silles, Mary Antonia

Publication date:

2005

Document version

Publisher's PDF, also known as Version of record

Citation for published version (APA):

Silles, M. A. (2005). Personality, Education and Earnings. Department of Economics, University of Copenhagen. 


\section{CAM}

\section{CAM}

Centre for Applied

Microeconometrics

Institute of Economics

University of Copenhagen

http://www.econ.ku.dk/CAMI

Personality, Education and Earnings

Mary A. Silles

2005-06

The activities of CAM are financed by a grant from

The Danish National Research Foundation 


\title{
PERSONALITY, EDUCATION AND EARNINGS
}

\author{
MARY A. SILLES
}

\begin{abstract}
This paper examines the effects of social maladjustment in childhood on schooling and earnings using the NCDS. Net of differences in family background and cognitive ability, estimates suggest that early social maladjustment scores are associated with lower labor market earnings and schooling. These results suggest that there are substantial returns to fostering positive social development in childhood.
\end{abstract}

\section{Introduction}

This paper examines the importance of social maladjustment in the determinants of educational qualifications and earnings. Studies of human capital formation have tended to focus on family background characteristics such as parental socio-economic status, parental education, order of birth as well as the results of cognitive tests to the exclusion of non-cognitive development. While these variables have almost always been shown to be important in predicting educational attainment, with the possible exception of cognition, they cannot be altered by schooling (see Dearden, 1998; Blundell et al., 2000). Research in the study of educational attainment has also examined the importance of school expenditure and teacher student ratios. Even if one takes into account the most favorable estimates from this literature, conventional measures of school quality have been shown to have little impact on education and future earnings (see Heckman et al., 1996; Dolton and Vignoles, 1996).

More recently, Carneiro and Heckman (2004) and Heckman (2000) stress the value of non-cognitive traits in the formation of human capital. Their concerns are founded on research which shows that non-cognitive skills are more malleable than cognition especially as children get older. For instance, the Perry Preschool Program demonstrates that early intervention programs do not permanently alter IQ even though the program 
participants experienced better socio-economic outcomes than children who did not receive the intervention (Schweinhart, 1993). One of the most important lessons to draw from the literature on successful early interventions is that the changes brought about by these programs were not the results of changes in cognition.

Empirical studies that focus on social adaptability and motivation tend to be scarce because of the lack of reliable data. Studies by Bowles and Gintis (1976), Edwards (1976) and Klein et al. (1991) show that job stability and dependability are traits greatly valued by employers as ascertained by supervisor ratings and questions of employers although they present no direct evidence on earnings and educational attainment. Other studies such as Bowles et al. (2001), have examined the effects of self-reported measures of persistence, self-esteem, optimism and the like on earnings and schooling outcomes. However, ex post assessments of self-esteem may be both cause and consequences of the labor market outcomes being investigated.

This paper makes use of a unique data set that includes information about an entire cohort of children born in Great Britain during one week in 1958. Information has been collected about these children from before birth until 2000. The early waves of the Study contain comprehensive family and schooling information while the later waves contain ample employment information. Most importantly for our purposes, the children were assessed on social maladjustment scales as well as on reading and mathematics at age 7 and again at age 11 . The literature on cognition ascertains that one dominant factor (' $\mathrm{g}$ ') describes cognition and their effects on various outcomes. In a similar way, this paper will use principal components analysis to try to identify social maladjustment scores from a multiplicity of variables describing the study child's social adaptability. Using this data, we augment the standard human capital model with new human capital variables to examine the role of personality traits in the determinants of earnings. We find that among British men, social maladjustment scores in childhood are strong predictors of education and earnings, independent of cognitive ability and socio-economic background. Most studies of ability bias in the estimated returns to education take omitted ability as cognitive ability and attempt to proxy the unobserved ability by cognitive tests. In this paper, we test and reject the hypothesis that the returns to education are biased upwards in earnings regression that excluded non-cognitive variables. 
The structure of this paper is as follows. Section II describes the data used in this study. In Section III we present our results. Section IV concludes the paper and offers some suggestions for further research.

\section{National Child Development Study}

The National Child Development Study (NCDS) is a continuing longitudinal study which is seeking to follow the lives of all those living in Great Britain who were born between $3^{\text {rd }}$ and $9^{\text {th }}$ of March, 1958. The study began with the Perinatal Mortality Survey aimed at uncovering the determinants of stillbirth and death. There have been six attempts to trace all members of the birth cohort. The survey sweeps were carried out in 1965 (age 7), in 1969 (age 11), in 1974 (age 16), in 1981 (age 23), in 1991 (age 33) and most recently in 1999-2000 (age 41-42). Table I presents the main summary information about these data.

TABLE I. SUMMARY OF SURVEY DATES AND SAMPLES

\begin{tabular}{lccccccc}
\hline & \multicolumn{7}{c}{ Survey Waves } \\
& Perinatal & 1 & 2 & 2 & 4 & 5 & 5 \\
\cline { 2 - 8 } Date of Survey & 1958 & 1965 & 1969 & 1974 & 1981 & 1991 & $1999-00$ \\
Largest Sample Size & 17,419 & 15,496 & 15,503 & 14,761 & 12,539 & 11,407 & 11,419 \\
Age of Respondent & 0 & 7 & 11 & 16 & 23 & 33 & $41-42$ \\
\hline
\end{tabular}

Table I demonstrates that the number of respondents has fallen steadily over time to about 66 percent of the initial sample size in 2000. Over all response rates have remained high, considering the length of the panel. Previous analysis of these data suggest that attriters are more likely than non-attriters to come from disadvantaged backgrounds, although observed differences between the two groups are quite small (Fogelman, 1976, 1983). In addition Robertson and Symons (1996), examining the distribution of test scores at ages 7 and 11 in regression models in earnings at age 33, concluded that the NCDS under-samples the lower end of the distribution as the cohort got older, but not by a significant amount.

The main goal of this paper is to examine the determinants of educational attainment and earnings. Our econometric specifications for the estimation of earnings are of the 
standard Mincerian form. The wage variable is the log of gross hourly wages computed by dividing usual gross weekly wages by usual hours worked per week ${ }^{1}$. Our measure of education is years of full-time education completed by age $23^{2}$.

One of the primary issues when attempting to understand the link between psychological traits and labor market outcomes is how to assess these traits. The NCDS includes a rich variety of personality measures including personality assessments that were taken prior to entry of the labor market and are thus exogenous to earnings. The present paper uses the 12-syndrome Bristol Social Adjustment Guide (BSAG) was administered to respondents at age 11. In order to maximize the information available, while reducing the number of dependent variables, scores at each age were combined using principal components analysis, and two factors were extracted, labeled aggression and withdrawal. A more complete explanation of the BSAG and the factor analysis results are presented in the Appendix.

The other important variables of interest for our purposes are the reading and mathematics tests at age 7. Economists have often interpreted these scores as measures of cognitive ability or innate ability as these tests are much less likely to be affected by schooling than later tests. As in Cawley et al. (1996) we measure intelligence by the first principal component from the two tests, which we simple labeled IQ ${ }^{3}$.

Family background characteristics are among the leading explanations for educational differences in children as they are proxy measures of monetary and non-monetary inputs into the child's educational development. Family socio-economic status is measured from the variables of father's socio-economic group at age 7 . These classes are regrouped into professional (professional, managerial, skilled non-manual) or non-professional groups (semi-skilled non manual, semi-skilled manual, unskilled). Persons without a father present at the time of the survey are assigned to the non-professional group. The father's educational attainment is described in the data as the age left full-time continuous

\footnotetext{
${ }^{1}$ The wages reported in the NCDS is somewhat cumbersome. Respondents were asked their usual weekly hours, their net and gross pay, and their pay interval. We first calculate the number of hours in the pay interval by examining the usual weekly hours, and then calculate the hourly pay rates by taking the pay reported and dividing by the number of hours in the pay interval. We focus on gross pay only and wages are deflated at 2000 prices.

${ }^{2}$ Since 1973 the minimum school leaving age in the UK is 16 years of age. Hence, our results are for postcompulsory or elective schooling.

3 Some 75 percent of the variation in scores can be explained by the first factor.
} 
education, which we express as years of education. The order of birth and sibling number is often used to predict investments in schooling (see Butcher and Case, 1994) and we use this information from the Perinatal Mortality Survey and the age 16 survey, respectively. Early measures of family background were used in general rather than later measures as recent research has shown that the early family environment is more important in explaining schooling (see evidence presented in Carneiro and Heckman, 2004; Duncan and Brooks-Gunn, 1997).

There are several other variables that we also use in predicting educational attainment. Recently the birth-weight of children has been used in educational attainment regressions and it is added in our models, too. The number of weeks the individual was away from school due to illness in 1973-74 is recorded in the data and also shown to be a significant determinant of education. Finally, we use information from the third wave of the survey to identify the type of school attended at age 16 (comprehensive, grammar, secondary modern, private or other).

Our sample is based on individuals who participated in the sixth sweep of the survey for whom there is relevant information on labour market status, wages, education, ability and social maladjustment scores. Our sample is restricted to individuals who are in fulltime employment with all self-employed and part-time workers being omitted. Individuals who were in care as children were also dropped from our sample. This leaves us with sample sizes of 972 individuals in $2000^{4}$. Summary statistics for these individuals are given in the appendix (Table IIA).

\section{Results}

To begin our assessment of the relationship between personality traits, wages and education, Table II compares summary statistics by above- and below-median maladjustment scores. These tabulations show that the average wages and average schooling levels are negatively associated with aggression and withdrawn levels. Ability also tends to be less associated with high social maladjustment levels. Remarkably, only slight differences in family background are apparent across social maladjustment levels.

\footnotetext{
${ }^{4}$ In our appendix we also report results based on the 1991 sample.
} 
This suggests that disparities in average adult outcomes on the basis of maladjustment levels are not very likely to reflect differences in these family characteristics.

TABLE II. SUMMARY STATISTICS BY SOCIAL MALADJUSTMENT LEVELS

\begin{tabular}{lcccc}
\hline \hline & $\begin{array}{c}\text { Aggression } \\
\text { Median or Less }\end{array}$ & $\begin{array}{c}\text { Aggression } \\
\text { Above Median }\end{array}$ & $\begin{array}{c}\text { Withdrawal } \\
\text { Median or Less }\end{array}$ & $\begin{array}{c}\text { Withdrawn } \\
\text { Above Median }\end{array}$ \\
\hline Aggression age 11 & -0.71 & 0.52 & -0.15 & -0.03 \\
& $(0.13)$ & $(0.95)$ & $(1.02)$ & $(0.80)$ \\
Withdrawn age 11 & -0.16 & 0.18 & -0.60 & 0.62 \\
& $(0.30)$ & $(1.28)$ & $(0.60)$ & $(0.83)$ \\
Log real hourly wages 2000 & 2.62 & 2.45 & 2.58 & 2.48 \\
& $(0.46)$ & $(0.46)$ & $(0.46)$ & $(0.47)$ \\
Schooling & 1.93 & 1.28 & 1.70 & 1.50 \\
& $(2.09)$ & $(1.51)$ & $(1.92)$ & $(1.77)$ \\
I.Q. age 7 & 0.30 & -0.12 & 0.18 & 0.00 \\
& $(0.88)$ & $(1.03)$ & $(0.90)$ & $(1.04)$ \\
Father's education & 10.00 & 9.90 & 10.03 & 9.87 \\
& $(1.82)$ & $(1.91)$ & $(1.98)$ & $(1.74)$ \\
Father professional & 0.34 & 0.29 & 0.33 & 0.30 \\
& $(0.47)$ & $(0.46)$ & $(0.47)$ & $(0.46)$ \\
Father non-professional & 0.66 & 0.71 & 0.67 & 0.70 \\
& $(0.47)$ & $(0.46)$ & $(0.47)$ & $(0.46)$ \\
Obs & 486 & 486 & 486 & 486 \\
\hline
\end{tabular}

To examine the determinants of schooling, we can specify a schooling equation of the following form:

$$
S_{i}=\chi Z_{i}+\varepsilon_{i}
$$

where $\mathrm{S}$ is years of elective schooling, $\mathrm{Z}$ is a matrix of variables which are thought to determine post-compulsory schooling, and $\varepsilon$ is the error term.

Table III reports the regression results with respect to educational attainment with varying sets of covariates. Three specifications are considered and all specifications include controls for family background characteristics, school type, birth-weight and illness. Column (1) controls for social maladjustment scores at age 11. The results suggest that aggression in the context of social development has a large and negative 
TABLE III. YEARS OF SCHOOLING

\begin{tabular}{|c|c|c|c|}
\hline & (1) & (2) & (3) \\
\hline Aggression & $\begin{array}{l}-0.231 \\
(0.047)^{* * *}\end{array}$ & & $\begin{array}{l}-0.170 \\
(0.048) * * *\end{array}$ \\
\hline Withdrawal & $\begin{array}{l}-0.011 \\
(0.042)\end{array}$ & & $\begin{array}{l}-0.000 \\
(0.043)\end{array}$ \\
\hline I.Q. age 7 & & $\begin{array}{l}0.333 \\
(0.058)^{* * *}\end{array}$ & $\begin{array}{l}0.297 \\
(0.058) * * *\end{array}$ \\
\hline Father professional & $\begin{array}{l}0.509 \\
(0.142)^{* * *}\end{array}$ & $\begin{array}{l}0.444 \\
(0.143)^{* * *}\end{array}$ & $\begin{array}{l}0.448 \\
(0.142)^{* * *}\end{array}$ \\
\hline Father's education & $\begin{array}{l}0.122 \\
(0.038)^{* * *}\end{array}$ & $\begin{array}{l}0.105 \\
(0.038) * * *\end{array}$ & $\begin{array}{l}0.106 \\
(0.038) * * *\end{array}$ \\
\hline Birth order & $\begin{array}{l}-0.063 \\
(0.058)\end{array}$ & $\begin{array}{l}-0.083 \\
(0.056)\end{array}$ & $\begin{array}{l}-0.079 \\
(0.057)\end{array}$ \\
\hline Number of siblings & $\begin{array}{l}-0.049 \\
(0.051)\end{array}$ & $\begin{array}{l}-0.017 \\
(0.051)\end{array}$ & $\begin{array}{l}-0.017 \\
(0.051)\end{array}$ \\
\hline Illness age 16 & $\begin{array}{l}-0.200 \\
(0.095)^{* *}\end{array}$ & $\begin{array}{l}-0.187 \\
(0.093)^{* *}\end{array}$ & $\begin{array}{l}-0.167 \\
(0.094)^{*}\end{array}$ \\
\hline Birth-weight & $\begin{array}{c}0.004 \\
(0.003)\end{array}$ & $\begin{array}{c}0.004 \\
(0.003)\end{array}$ & $\begin{array}{c}0.004 \\
(0.003)\end{array}$ \\
\hline School-Comprehen & & & \\
\hline Grammar & $\begin{array}{l}1.211 \\
(0.249)^{* * *}\end{array}$ & $\begin{array}{l}1.026 \\
(0.252)^{* * *}\end{array}$ & $\begin{array}{l}1.030 \\
(0.250)^{* * *}\end{array}$ \\
\hline Secondary modern & $\begin{array}{l}-0.238 \\
(0.114)^{* *}\end{array}$ & $\begin{array}{l}-0.166 \\
(0.112)\end{array}$ & $\begin{array}{l}-0.169 \\
(0.112)\end{array}$ \\
\hline Private & $\begin{array}{l}1.991 \\
(0.399)^{* * *}\end{array}$ & $\begin{array}{l}1.884 \\
(0.408)^{* * *}\end{array}$ & $\begin{array}{l}1.871 \\
(0.406)^{* * *}\end{array}$ \\
\hline Other & $\begin{array}{r}-0.188 \\
(0.238)\end{array}$ & $\begin{array}{l}0.002 \\
(0.262)\end{array}$ & $\begin{array}{c}0.109 \\
(0.282)\end{array}$ \\
\hline Constant & $\begin{array}{l}-0.025 \\
(0.546)^{* * *}\end{array}$ & $\begin{array}{l}0.149 \\
(0.547)^{* * *}\end{array}$ & $\begin{array}{l}0.108 \\
(0.542)^{* * *}\end{array}$ \\
\hline Obs & 972 & 972 & 972 \\
\hline$\underline{\mathrm{R} \text {-squared }}$ & 0.24 & 0.25 & 0.26 \\
\hline
\end{tabular}

Robust standard errors in parentheses

* significant at $10 \%$;* significant at $5 \% ; * * *$ significant at $1 \%$

effect on educational attainment whereas withdrawal is not shown to be statistically significant.

Numerous articles on the studies of educational attainment have shown that cognitive ability, measured by test scores, is an important predictor of education. In column (2) we examine the impact of ability at age 7 on schooling. The results are clearly in line with expectations. Higher ability individuals have higher schooling levels. However, it is not clear whether measured cognitive ability should be included in regressions that contain 
measures of social maladjustment at the same or later ages. This is due to the fact that we cannot tell whether more able individuals develop greater non-cognitive skills or were they are more able because of non-cognitive development. Nevertheless, in column (3) we include both social maladjustment scores at age 11 and ability at age 7 . The coefficient on aggression is significantly revised downwards. The results reveal that a one standard deviation change in aggression reduces schooling levels by 0.17 of a year. Cognitive ability is still very important with a one standard deviation change in ability increasing schooling by approximately 0.30 of a year. The coefficients on withdrawal scores remain statistically insignificant.

Finally examining the control variables, our results are largely consistent with other literature in this field. Family background characteristics and school type make important contributions to educational attainment among children. Spells of illness lower schooling but birth-weight, family size and birth order are not shown to be statistically significant ${ }^{5}$.

To account for the effects of social maladjustment on earnings, our approach is to augment a cross-section earnings equation to include the aggression and withdrawn scores. We adopt a log-linear specification:

$$
\ln y_{i}=\alpha+\beta X_{i}+\delta S_{i}+\mu_{i}
$$

where $\mathrm{y}$ refers to real gross hourly wages, $\mathrm{X}$ is a vector of social maladjustment (aggression and withdrawn), S represents years of elective schooling, and $\mu$ is the error term.

The estimation of equation (2) by OLS will lead to a biased estimate of the returns to schooling if there is selection into elective schooling or measurement error in schooling (see Card, 1995 for an extensive discussion of the direction of this bias). What is important for our purposes is that the other coefficients in the regression will typically be biased, too. The direction of the bias will depend on the sign of the correlation between

\footnotetext{
${ }^{5}$ The sample analysis for our 1991 sample shows that birth-weight and order of birth were statistically significant.
} 
the error terms in equations (1) and (2). It is standard practice to use Instrument Variable (IV) methods to correct for this potential endogeneity.

Table IV presents the results of fitting the above equation by OLS and IV. Columns (1) and (2) give baseline estimates of the effects of social maladjustment scores and schooling on hourly earnings at age 42 , respectively. These regression models do not include any other covariates and form a baseline, which can be compared with later models. The social maladjustment scores are statistically significant and relatively large.

Incorporating both social maladjustment scores and schooling in the same regression, we notice that the addition of education revises the estimates on aggression significantly downwards while the estimated coefficients on withdrawal are not much reduced. The estimates of the returns to education are not significantly different when we control for social maladjustment scores than when we excluded these variables, which signifies that there is no notable bias in the returns to education due to the omission of these abilities.

TABLE IV. OLS AND IV ESTIMATES (EARNINGS 2000)

\begin{tabular}{lllllll}
\hline \hline & \multicolumn{1}{c}{ OLS } & OLS & OLS & OLS & OLS & IV \\
& $(1)$ & $(2)$ & $(3)$ & $(4)$ & $(5)$ & $(6)$ \\
\hline \multirow{2}{*}{ Aggression } & -0.106 & & -0.078 & -0.059 & -0.059 & -0.047 \\
& $(0.017)^{* * *}$ & & $(0.016)^{* * *}$ & $(0.017)^{* * *}$ & $(0.016)^{* * *}$ & $(0.017)^{* *}$ \\
Withdrawal & -0.048 & & -0.044 & -0.040 & -0.035 & -0.034 \\
& $(0.015)^{* * *}$ & & $(0.014)^{* * *}$ & $(0.014)^{* * *}$ & $(0.014)^{* *}$ & $(0.014)^{* *}$ \\
Schooling & & 0.091 & 0.084 & 0.070 & 0.069 & 0.132 \\
& & $(0.008)^{* * *}$ & $(0.008)^{* * *}$ & $(0.008)^{* * *}$ & $(0.008)^{* * *}$ & $(0.022)^{* *}$ \\
I.Q. age 7 & & & & 0.094 & 0.090 & 0.055 \\
& & & & $(0.015)^{* * *}$ & $(0.015)^{* * *}$ & $(0.020)^{* * *}$ \\
Married & & & & & 0.058 & 0.054 \\
& & & & & $(0.040)$ & $(0.041)$ \\
Children & & & & & 0.086 & 0.088 \\
& & & & & $(0.035)^{* *}$ & $(0.036)^{* *}$ \\
Union & & & & -0.030 & -0.015 \\
& & & & $(0.026)$ & $(0.028)$ \\
Constant & 2.524 & 2.387 & 2.391 & 2.408 & 2.318 & 2.217 \\
& $(0.015)^{* * *}$ & $(0.018)^{* * *}$ & $(0.018)^{* * *}$ & $(0.018)^{* * *}$ & $(0.036)^{* * *}$ & $(0.050)^{* * *}$ \\
Obs & 972 & 972 & 972 & 972 & 972 & 972 \\
R-squared & 0.05 & 0.13 & 0.16 & 0.19 & 0.21 & 0.16 \\
\hline
\end{tabular}

Robust standard errors in parentheses

* significant at $10 \% ; * *$ significant at $5 \% ; * * *$ significant at $1 \%$ 
Column (4) introduces cognitive ability at age 7. The coefficient on cognition is statistically significant and indicates that a one standard deviation increase improves earnings by 9.4 percent. The estimated coefficient on aggression declines to 5.9 percent but the coefficient on withdrawal remains robust at approximately 4 percent. The returns to educational are not significantly revised downwards.

Column (5) introduces more comprehensive controls for marital status, children and trade union affiliation, which are normal in earnings regression. The results yield estimated returns to social maladjustment scores, schooling and ability that are not significantly different from those presented in regressions without these variables.

Finally, column (6) shows the corresponding IV estimates based on results presented in column (3) of Table III. The instruments used for identification are father's socioeconomic group, the father's years of education, birth order, family size, birth-weight, illness and school attended. Family background variables were successfully used by Harmon and Walker (2000) and Dearden (1995) and the use of birth weight was highlighted in Behrman et al. (1994). These authors found that family background and nutritional intake in the womb influences early investment in education but net of schooling has no subsequent impact on earnings. Of the instruments used in our study, father's socio-economic group, years of education, illness and school type were statistically significant.

It is immediately apparent that the OLS estimated return to schooling is much smaller than that estimated by IV. The OLS results show an estimate of approximately 7 percent, while the IV results suggest a rate of return of approximately 13 percent. These higher IV results concur with the findings of Harmon and Walker $(1995,2000)$ whereby the IV estimated returns to education are much higher than OLS. The returns to cognitive ability are significantly reduced from 9 percent to 5.5 percent. The other covariates including the social maladjustment scores are not statistically different from those of the OLS estimation.

\section{Conclusion}

This paper assesses the role of social maladjustment in childhood in explaining labor market earnings and schooling. Using data from the National Child Development Study, 
we found that childhood social competence is significantly correlated with educational attainment and future labor market earnings. In particular, early childhood measures of aggression linked with social maladjustment at age 11 lower lifelong schooling outcomes and earnings, irrespective of family background characteristics and cognitive ability. The rate of return to schooling was not significantly changed in earnings regressions that took account of social maladjustment measures, indicating no bias in the returns to schooling that emerge from standard human capital earnings functions.

The findings of this paper demonstrate that cognitive and non-cognitive abilities early in childhood persist and have permanent effects. The pathways of non-cognitive development are far from clear. Part of the success of high-quality early intervention programs, such as the Perry Preschool Program, has been credited to a parental component as there were regular teacher visits to the children homes. Indeed, the outstanding quality of teachers and other professionals involved in the Perry Program are believed to have made a vast difference to the learning of participants in comparison with similar programs of a lower cost. Though current research in education focuses on schools, further research needs to place greater emphasis on family and individual teacher input. 


\section{Appendix}

\section{NCDS: Bristol Social Adjustment Scores}

The National Child Development Study (NCDS) is a continuing longitudinal study which is seeking to follow the lives of all those living in Great Britain who were born between $3^{\text {rd }}$ and $9^{\text {th }}$ of March 1958. The aim of the study is to improve understanding of the factors affecting human development over the whole lifespan. The NCDS has gathered data from respondents on child development from birth to early adolescence, child care, medical care, health, physical statistics, school readiness, home environment, educational progress, parental involvement, cognitive and social growth, family relationships, economic activity, income, training and housing. The purpose of The Bristol Social Adjustment Guide study is to assess the children's social adjustment at age 7 and 11 . The BSAG consists of some 146 behavioral items that were evaluated by the teacher. Topics are divided into sections, such as 'attitudes to teacher', 'attitudes towards other children', etc. For each topic the informant is given a choice of approximately $6-8$ statements to describe the child. The forms used are those devised by Stott (1965) and known as the 'Bristol Social Adjustment Guides'. The 146 items were reported as 12 syndromes.

TABLE IA. PRINCIPAL COMPONENTS FACTOR ANALYSIS BSAG AGE 11

\begin{tabular}{lcc}
\hline Age 11 BSAG Syndrome & $\begin{array}{c}\text { Factor 1 } \\
\text { Aggression }\end{array}$ & $\begin{array}{c}\text { Factor 2 } \\
\text { Withdrawal }\end{array}$ \\
\hline Unforthcomingness & & \\
Withdrawal & 0.341 & 0.733 \\
Depression & 0.480 & 0.619 \\
Anxiety & 0.671 & 0.390 \\
Hostility towards adults & 0.383 & -0.409 \\
Writing off adults \& standards & 0.694 & -0.209 \\
Anxiety for acceptance by kids & 0.697 & 0.180 \\
Hostility towards children & 0.590 & -0.477 \\
Restlessness & 0.669 & -0.289 \\
Inconsequential behavior & 0.567 & -0.249 \\
Miscellaneous symptoms & 0.772 & -0.267 \\
Miscellaneous nervous symptoms & 0.626 & 0.329 \\
\hline
\end{tabular}


TABLE IIA SUMMARY STATISTICS

\begin{tabular}{lcccc}
\hline \hline & 1991 & & 2000 & \\
& Mean & Std. Dev & Mean & Std. Dev \\
\hline Log real hourly wages (2000 prices) & 2.181 & 0.422 & 2.533 & 0.467 \\
Schooling & 1.643 & 1.912 & 1.603 & 1.848 \\
Aggression age 11 & -0.078 & 0.926 & -0.093 & 0.918 \\
Withdrawal age 11 & 0.023 & 0.949 & 0.008 & 0.947 \\
Ability age 7 & 0.062 & 0.981 & 0.090 & 0.980 \\
Birth order & 1.068 & 1.309 & 1.039 & 1.267 \\
Number of siblings age 16 & 2.186 & 1.661 & 2.136 & 1.566 \\
Illness (weeks) age 16 & 1.405 & 0.599 & 1.400 & 0.573 \\
Birth weight & 121.004 & 17.935 & 120.912 & 17.753 \\
Comprehensive & 0.544 & 0.498 & 0.533 & 0.499 \\
Grammar & 0.106 & 0.308 & 0.098 & 0.297 \\
Secondary modern & 0.185 & 0.388 & 0.193 & 0.395 \\
Private & 0.043 & 0.202 & 0.044 & 0.206 \\
Other & 0.006 & 0.079 & 0.006 & 0.078 \\
Father professional age 7 & 0.312 & 0.463 & 0.316 & 0.465 \\
Father non-professional age 7 & 0.688 & 0.463 & 0.684 & 0.465 \\
Father's years of education & 9.931 & 1.832 & 9.950 & 1.863 \\
Married (0,1) & 0.734 & 0.442 & 0.772 & 0.420 \\
Children (0,1) & 0.657 & 0.475 & 0.683 & 0.465 \\
Union (0,1) & 0.441 & 0.497 & 0.440 & 0.497 \\
\hline
\end{tabular}


TABLE 3A. OLS AND IV ESTIMATES (EARNINGS 1991)

\begin{tabular}{|c|c|c|c|c|c|c|}
\hline & $\begin{array}{l}\text { OLS } \\
(1)\end{array}$ & $\begin{array}{l}\text { OLS } \\
(2)\end{array}$ & $\begin{array}{l}\text { OLS } \\
(3)\end{array}$ & $\begin{array}{l}\text { OLS } \\
(4)\end{array}$ & $\begin{array}{c}\text { OLS } \\
(5) \\
\end{array}$ & $\begin{array}{l}\text { IV } \\
(6)\end{array}$ \\
\hline Aggression & $\begin{array}{l}-0.075 \\
(0.012)^{* * *}\end{array}$ & & $\begin{array}{l}-0.051 \\
(0.010)^{* * *}\end{array}$ & $\begin{array}{l}-0.033 \\
(0.011)^{* * *}\end{array}$ & $\begin{array}{l}-0.033 \\
(0.011)^{* * *}\end{array}$ & $\begin{array}{l}-0.021 \\
(0.011)^{*}\end{array}$ \\
\hline Withdrawal & $\begin{array}{l}-0.046 \\
(0.011)^{* * *}\end{array}$ & & $\begin{array}{l}-0.043 \\
(0.010) * * *\end{array}$ & $\begin{array}{l}-0.037 \\
(0.010)^{* * *}\end{array}$ & $\begin{array}{l}-0.033 \\
(0.010)^{* * *}\end{array}$ & $\begin{array}{l}-0.034 \\
(0.011) * * *\end{array}$ \\
\hline I.Q. age 7 & & & & $\begin{array}{l}0.087 \\
(0.012)^{* * *}\end{array}$ & $\begin{array}{l}0.086 \\
(0.012)^{* * *}\end{array}$ & $\begin{array}{l}0.036 \\
(0.016)^{* *}\end{array}$ \\
\hline Schooling & & $\begin{array}{l}0.082 \\
(0.005)^{* * *}\end{array}$ & $\begin{array}{l}0.077 \\
(0.005)^{* * *}\end{array}$ & $\begin{array}{l}0.064 \\
(0.005)^{* * *}\end{array}$ & $\begin{array}{l}0.066 \\
(0.005)^{* * *}\end{array}$ & $\begin{array}{l}0.147 \\
(0.016)^{* * *}\end{array}$ \\
\hline Married & & & & & $\begin{array}{l}0.064 \\
(0.026)^{* *}\end{array}$ & $\begin{array}{l}0.056 \\
(0.028) * *\end{array}$ \\
\hline Children & & & & & $\begin{array}{c}0.027 \\
(0.023)\end{array}$ & $\begin{array}{l}0.061 \\
(0.026)^{* *}\end{array}$ \\
\hline Union & & & & & $\begin{array}{c}0.031 \\
(0.020)\end{array}$ & $\begin{array}{l}0.038 \\
(0.021)^{*}\end{array}$ \\
\hline Constant & $\begin{array}{l}0.343 \\
(0.011)^{* * *}\end{array}$ & $\begin{array}{l}0.213 \\
(0.013)^{* * *}\end{array}$ & $\begin{array}{l}0.217 \\
(0.013)^{* * *}\end{array}$ & $\begin{array}{l}0.235 \\
(0.013)^{* * *}\end{array}$ & $\begin{array}{l}0.154 \\
(0.026)^{* * *}\end{array}$ & $\begin{array}{c}0.005 \\
(0.039)\end{array}$ \\
\hline Obs & 1427 & 1427 & 1427 & 1427 & 1427 & 1427 \\
\hline$\underline{\mathrm{R} \text {-squared }}$ & 0.04 & 0.16 & 0.16 & 0.19 & 0.20 & 0.08 \\
\hline
\end{tabular}

Robust standard errors in parentheses

*significant at $10 \%$; ${ }^{* *}$ significant at $5 \%$; *** significant at $1 \%$ 


\section{References}

Bartel, A.P., and P. Taubman (1986) "Some Economics and Demographic Consequences of Mental Illness,” Journal of Labor Economics, 243-56.

Bowles, S. and H. Gintis (1976), Schooling in Capitalist America. New York: Basic Books.

Bowles, S, H. Gintis and M. Osborne (2001), "The Determinants of Earnings: A Behavioral Approach", Journal of Economic Literature, 39: 1137-1176.

Butcher, K. and A. Case (1994), “The Effect of Sibling Composition on Women's Education and Earnings", Quarterly Journal of Economics, vol. 106 (3), pp. 531-64

Card, D. (1993), "Using Geographical Variation in College Proximity to Estimate the Returns to Schooling”, National Bureau of Economic Research Working Paper No. 4832.

Carneiro and Heckman (2004), :The Evidence on Credit Constraints in Post-Secondary Schooling", Economic Journal, 112 (482): 705-734.

Cawley, J., J. Heckman and E. Vytlacil (2001) “Three Observations on Wages and Measured Cognitive Ability," Labor Economics 8: 419-442.

Cawley,John, Karen Conneely, James Heckman and Edward Vytlacil (1996). "Measuring the Effects of Cognitive Ability", National Bureau of Economic Research Working Paper Series no.5645.

Coleman, M. and T. DeLeire (2000) “An Economic Model of Teenagers” Locus of Control and High School Graduation Decisions," Unpublished manuscript, University of Chicago. 
Coleman, J. and T. Hoffer (1983), Public and Private High Schools. New York: Basic Books.

Dearden, L. (1998), “Qualifications and Earnings in Britain: How Reliable are Conventional OLS Estimates of the Returns to Education?”, Institute for Fiscal Studies, Working Paper Number 99/07.

Dearden L., Ferrier, J. and C. Meghir (1997), "The Effects of School Quality on Educational Attainment and Wages, mineo, Institute for Fiscal Studies.

Dolton P. and A. Vignoles, 1996, "The Impact of School Quality on Labour Market Success in the United Kingdom”, University of Newcastle, unpublished mimeo.

Edwards, R. (1976), "Individual Traits and Organizational Incentives: What Makes a Good Worker?", Journal of Human Resources, 11(1): 51-68.

Feinstein, L., (2000), "The Relative Economic Importance of Academic, Psychological and Behavioural Attributes Developed in Childhood", London School of Economics, Centre for Economic Performance, Working Paper Number 0443.

Fogelman, K. (1983), Growing Up in Great Britain: Papers from the National Child Development Study. London: MacMillan.

Fogelman, K. (1976), Britain's Sixteen-Year-Olds, London: National Children's Bureau.

Frank, R.G., and P.J. Gertler (1991) "Assessment of the Measurement Error Bias for Estimating the Effect of Mental Distress on Income," Journal of Human Resources, 15464. 
Goldsmith, A.H., J.R. Veum and W. Darity, Jr. (1997) "The Impact of Psychological and Human Capital on Wages," Economic Inquiry 35: 815-829.

Gregg, P. and S. Machin (1998), "Child Development and Success or Failure in the Youth Labour Market”, London School of Economics, Centre for Economic Performance, Discussion Paper Number 0397,

Harmon, C. and I. Walker (2000), "The Returns to Quantity and Quality of Education: Evidence for Men in England and Wales”, Economica, 67: 19-35.

Harmon, C. and I. Walker (1995), "Estimates of the Economic Returns to Schooling for the United Kingdom”, American Economic Review, 85(5): 1278-86.

Heckman, J. (2000), 'Policies to Foster Human Capital”, Research in Economics, 54 (1): $3-56$

Heckman, J., A. Layne-Farrar and P. Todd (1996), "Human Capital Pricing Equations with an Application to Estimating the Effects of Schooling Quality on Earnings”, The Review of Economics and Statistics, 78(6): 562-610.

Heckman, J. (1995), “A Life-Cycle Model of Earnings, Learning and Consumption”, in O. Ashenfelter and K. Hallock, eds., Labor Economics, Vol. 2. Brookfield, VT: Elgar/Ashgate.

Heckman, J. (1990), 'Varieties of Selection Bias', American Economic Review, vol. 80(2) pp. 313-18.

Heckman, J. (1979), "Sample Section Bias as a Specification Error”, Econometrica, vol. 47(1), pp. 153-61. 
Klein, R., R. Spady and A. Weiss (1991), "Factors Affecting the Output and Quit Propensities of Production Workers,", Review of Economic Studies, 52(2): 929-54.

Mullahy, J., and J.L. Sindelar (1993) “Alcoholism, Work, and Income,” Journal of Labor Economics, 494-520.

Neal. D. (1997), "The Effects of Catholic Secondary Schooling on Educational Achievement", Journal of Labor Economics, 15(1): 98-123.

Osborne, M. (1999) "Personality and Labor Market Success," Unpublished manuscript, University of Massachusetts - Amherst.

Pagan, A. (1984), "Econometric Issues in the Analysis of Regressions with Generated Regressors", International Economic Review, vol. 25(1), pp. 221-47.

Robertson, D. and J. Symons (1996), "Do Peer Groups Matter? Peer Groups Versus Schooling Effects on Educational Attainment”, LSE Centre for Economic Performance, Working Paper Number 0311.

Schweinhart, L. J. (2003). Benefits, Costs, and Explanation of the High/Scope Perry Preschool Program. High/Scope Educational Research Foundation Paper presented at the Meeting of the Society for Research in Child Development Tampa, Florida April 26.

Stott, P. (1965), Manual of the Bristol Social Adjustment Guide. 